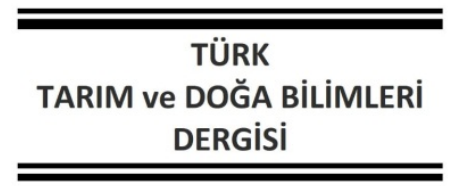

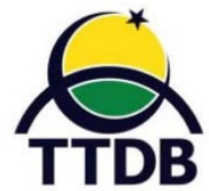

www.dergipark.gov.tr/turkjans

Araştırma Makalesi

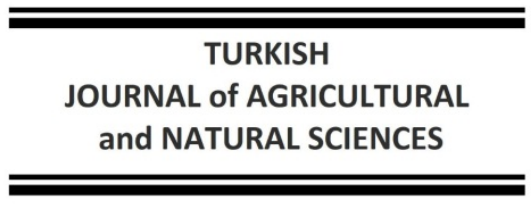

OURAL OF AGRICULTURAL

\title{
İç mekân Süs Bitkileri Tüketici Tercihlerinin Belirlenmesi; Zonguldak Kenti Örneği
}

\author{
Şüheda Basire AKÇA \\ Zonguldak Bülent Ecevit Üniversitesi, Çaycuma Gıda ve Tarım Meslek Yüksekokulu, Park ve Bahçe Bitkileri \\ Bölümü, Zonguldak \\ Sorumlu Yazar: sbasire.akca@beun.edu.tr
}

Geliş Tarihi: 11.02.2021 Düzeltme Geliş Tarihi: 24.03.2021 Kabul Tarihi: 08.04.2021

\section{Öz}

Süs bitkileri, yapay olarak oluşturulmuş alanlarda yaşam kalitesini yükselten ve dolayısıyla insan sağlı̆̆ı ve psikolojisi üzerine olumlu etkileri bulunan önemli bir sektördür. İç mekânlarda kullanılan süs bitkileri doğa ile iç mekânın bağını kurmaktadır. Ayrıca iç mekân süs bitkileri; yıl boyunca canlı olmaları, yaprak, gövde özellikleri, renk, koku ve formları ile kullanıldıkları mekânların daha çekici ve canlı hale gelmesini sağlamaktadır. Bu araştırmada, Zonguldak kenti örneğinde iç mekân süs bitkilerine yönelik tüketim eğilimleri ve satın alma davranışlarını saptamak amacıyla anket çalışması yapılmıştır. Araştırma materyalini, Zonguldak kentinde ikamet eden süs bitkileri tüketicileri ve tüketicilere uygulanan yüz yüze anket çalışması ile elde edilen veriler oluşturmaktadır. Anket sonuçları SPSS istatistik paket programı ile analiz edilmiştir. Ankete katkı sağlayanların çoğunluğu, 31-45 yaş aralığındadır. Araştırma sonucunda; en fazla tercih edilen iç mekân süs bitkilerinin sırasıyla Phalaenopsis sp. (orkide), sukulent-kaktüs ve Saintpaulia ionantha (menekşe) olduğu görülmüştür. Bunun yanı sıra tüketiciler iç mekân süs bitkilerini; \% 87,2'si doğrudan satışla almayı tercih ederken, \% 12,8'si ise telefonla siparişle satın almaktadır.

Anahtar kelimeler: İç mekân süs bitkileri, tüketici tercihleri, Zonguldak

\section{Determining Consumer Preferences for Indoor Ornamental Plants; A Case of Zonguldak \\ City}

\begin{abstract}
Ornamental plants are an important sector that improves the quality of life in artificially created areas and thus has positive effects on human health and psychology. Ornamental plants used indoors establish the link between nature and the interior. In addition, indoor ornamental plants; Their liveliness throughout the year makes the places they are used more attractive and lively with their leaf, stem features, color, scent and forms. In this study, a survey was conducted to determine the consumption trends and purchasing behaviors of indoor ornamental plants in the example of Zonguldak city. The research material consists of the data obtained through face-to-face survey study applied to ornamental plant consumers and consumers residing in the city of Zonguldak. The survey results were analyzed with the SPSS statistical package program. The majority of the contributors to the survey are between the ages of 31-45. As a result of the research; It has been observed that the most preferred indoor ornamental plants are Phalaenopsis sp. (orchid), succulent-cactus and Saintpaulia ionantha (violet), respectively. In addition, consumers can buy indoor ornamental plants; $87.2 \%$ of them prefer to buy directly, $12.8 \%$ of them buy by phone.
\end{abstract}

Keywords: Indoor ornamental plants, consumer preferences, Zonguldak 


\section{Giriş}

Süs bitkileri; gösterişli çiçekleri, meyveleri, dalları, yaprakları ile bulundukları ortama estetik ve fonksiyonel açıdan benzersiz bir katkı sağlamaktadır. Birçok kültürde de süs bitkileri güzellik ve sanatın ifadesi olarak yaşama anlam katmıştır (Titiz ve ark., 2000a; Titiz ve ark., 2000b).

İç ve dış mekânlardaki süs bitkileri, evlerimizin ve ofislerimizin estetiğini geliştirirken daha yeşil bir ortamda yaşamamızı sağlamaktadır. Doğada ki açan bir çiçeğe veya bir herhangi ağaca bakmanın mutluluk oranını artırması ile süs bitkilerine duyulan ihtiyaç insanların genel refahı açısından da önemli hale gelmektedir. Aynı zamanda süs bitkileri çeşitli şekilde fayda sağlayarak bazı duyularımıza hitap etmektedir. Süs bitkilerinin hem görsel hem de koku alma duyusuna hitap etmelerinin yanı sıra sakinleştirici etkisi de bulunmaktadır. Ek olarak,mekâna canlılık katmak, monotonluğu gidermek, sınırlandırma, gölgeleme ve yönlendirme gibi olumlu katkılar sağlamaktadır (Yazıcı ve Gülgün 2016; Sezen ve ark., 2017; Selim ve ark. 2020).

1970'lerin başından bu yana insanlar üzerinde bitkilerin faydaları yapılan bilimsel araştırmalarla kabul edilmiştir. 20. yüzyılın ikinci yarısında yapılan araştırmalar da ise, doğa göz önünde alınarak yapılan iç mekan tasarlamanın insan yaşam kalitesi üzerinde olumlu etkileri bildirilmiştir (Ulrich, 1984; Kellert, 2005; Husti ve ark., 2015). Diğer çalışmalarda, iç mekânlarda süs bitkilerinin bulunmasının hafızayı ve konsantrasyonu iyileştirmeye yardımcı olabileceğini ve daha iyi üretkenlik sağlayabileceğinin göstermektedir. Ofislerdeki iç mekân bitkileri, çalışanların zihinsel yorgunluktan kurtulmasına ve stres düzeyini azaltarak verimliliklerini artırmaktadır (Dijkstra ve ark., 2008; Husti ve ark., 2015). Aynı zamanda iç mekan süs bitkileri; gürültüyü filtre etmeleri, akustik kontrolü sağlamaları, tozu tutmaları, parlamayı ve yansımayı önlemeleri ile ışığı kontrol altına almaları ve oksijen üreterek havayı temizlemeleri nedeni ile ekolojik işlevlere de sahiptir (Yazgan ve ark., 2009; Zencirkıran ve ark., 2018).

Son yıllarda dünyadaki hızlı kentleşme ile birlikte yeşil alanları oluşturan süs bitkilerin önemi gün geçtikçe artarak devam etmektedir (Yeşilayer ve ark., 2019). Özellikle 2020 yılında dünyayı etkisi altına alan pandemi sürecinde süs bitkilerine olan ihtiyacın daha fazla arttığı görülmektedir. İnsanların sokağa çıkma kısıtlamalarını yaşadığı ve evlerine kapandıkları bu dönemde doğa özlemiyle beraber süs bitkilerinin hayatımızdaki önemi anlaşılmıştır. Tüketim tercihlerinin belirlenmesi de bu anlamda önemli olmuştur.Tüketici tercihleri ile ilgili farklı alanlarda birçok araştırma yapılmıştır (Gözener ve
Sayılı, 2013; Sayılı ve Gözener, 2013, Büyükbay Oruç ve ark., 2017). Ancak süs bitkilerinde tercihlerin belirlenmesi ile ilgili çalışma ülkemizde çok az sayıdadır.

Bu çalışmanın amacı, Zonguldak kentinde tercih edilen iç mekân süs bitkilerini ve tüketici tercihlerini belirlemek amacıyla yapılmıştır. Yapılan bu çalışma ile elde edilen veriler; üreticilerin üretim planlamaları için veri tabanı oluşturarak bu yönde yeni stratejiler geliştirmesi ve çağımızın gerekleri doğrultusunda yatırımlar yapmasına katkı sağlayacaktır.

\section{Materyal ve Metot}

Araştırma materyalini, Zonguldak kentinde ikamet eden süs bitkileri tüketicileri ve tüketicilere uygulanan yüz yüze anket çalışması ile elde edilen veriler oluşturmaktadır. Bu çalışma 2019 yılı NisanKasım ayları arasında yüz yüze anket çalışması ile elde edilen veriler doğrultusunda gerçekleştirilmiştir. Araştırmada kolayda örnekleme yöntemi iç mekân süs bitkilerini perakende satan firmanın yıllık satışı üzerinden ortalama aylık tüketici sayısı belirlenmiştir (Yazıcı, 2020). Çalışmada gönüllük esasına göre toplam 100 kişiye anket uygulanmıştır. Anket çalışmasında araştırma kitlesine canlı çiçek (iç mekân süs bitkileri ve kesme çiçek) tüketim tercihlerine göre demografik bilgileri ve tercih nedenleri sorulmuştur. Ankette iç mekân süs bitkilerine yönelik ise tüketicilere tercih ettikleri; bitki, bitki rengi, özel gün, satın alma yöntemi ve bakım bilgisi ile ilgili sorular sorulmuştur. Anket sonucunda elde edilen veriler SPSS istatistik paket programı ile analiz edilmiştir. Verilerin analizinde yöntem olarak betimsel analizler (Frequency ve Descriptive) ve gruplar arası karşılaştırmada Khi-Kare testi kullanılmıştır.

\section{Bulgular ve Tartışma Ankete katılan kişilerin sosyo-demografik özellikleri}

Zonguldak ilindeki 100 geçerli anketi yapan kişilerin cinsiyet ve yaş grupları dağılımları Tablo $1 a^{\prime}$ da gösterilmektedir. Ankete katılanların 47'si iç mekân süs bitkisini tercih ederken 53 kişi ise kesme çiçek tercih etmiştir. Schimmenti ve ark. (2013)'nın yaptıkları anket çalışması sonucuna göre; en fazla iç mekân (saksılı) süs bitkilerinin $(\% 65,75)$ satın alındığı, geri kalan katılımcıların hem iç mekân hem de kesme çiçekleri (\% 25) veya sadece kesme çiçeklerinin $(\% 9,25)$ tercih edildiği belirtilmiştir.

İç mekân süs bitkisi tercih edenlerin \% 57,4'ü (27 kişi) kadın iken \% 42,6'sı (20 kişi) erkektir. Kesme çiçek satın alanların ise \% 54,7'si (29 kişi) kadın, \% 45,3'ü (24 kişi) erkektir. 
Schimmenti ve ark. (2013); Anacleto ve ark., (2017); Sezen ve ark., (2017) yaptıkları çalışmalarda ankete katılan kadın katılımcıların erkeklerden daha fazla olduğunu belirtmişlerdir. Çalışmanın verileri ile Schimmenti ve ark. (2013), Anacleto ve ark., (2017), Sezen ve ark., (2017) ile paralellik göstermektedir. Yaş grubuna göre iç mekân süs bitkisini en fazla $31-45$ yaş grubu $(\% 55,3)$, en az ise $46-60$ yaş grubu (\% 17) tercih etmektedir (Tablo 1a.).

Tablo 1a. Demografik özellikler (Cinsiyet ve yaş grupları).

\begin{tabular}{|c|c|c|c|c|c|}
\hline \multicolumn{2}{|c|}{ Demografik özellikler } & \multicolumn{2}{|c|}{$\begin{array}{c}\text { İç mekân süs bitkisi tercih } \\
\text { edenler }\end{array}$} & \multicolumn{2}{|c|}{$\begin{array}{c}\text { Kesme çiçek süs bitkisi tercih } \\
\text { edenler }\end{array}$} \\
\hline & & Kişi sayısı & $\%$ & Kişi sayısı & $\%$ \\
\hline \multirow{3}{*}{ Cinsiyet } & Kadın & 27 & 57,4 & 29 & 54,7 \\
\hline & Erkek & 20 & 42,6 & 24 & 45,3 \\
\hline & $16-30$ & 13 & 27,7 & 33 & 62,3 \\
\hline \multirow{2}{*}{$\begin{array}{l}\text { Yaş } \\
\text { grupları }\end{array}$} & $31-45$ & 26 & 55,3 & 17 & 32,1 \\
\hline & $46-60$ & 8 & 17,0 & 3 & 5,7 \\
\hline \multirow{2}{*}{ Yaş } & $\begin{array}{l}\text { İç mekân süs bitkisi } \\
\text { tercih edenler }\end{array}$ & \multicolumn{2}{|c|}{$\mathrm{N}: 47$} & \multicolumn{2}{|c|}{ St sapma: 0,667 } \\
\hline & $\begin{array}{l}\text { Kesme çiçek süs bitkisi } \\
\text { tercih edenler }\end{array}$ & \multicolumn{2}{|c|}{$N: 53$} & \multicolumn{2}{|c|}{ St sapma:0,605 } \\
\hline
\end{tabular}

Anket sonuçlarına göre iç mekân süs bitkilerini tercih edenlerin \%87,2'si evli iken \%12,8'i ise bekârdır. İç mekân süs bitkisini satın alanların yarısından fazlası; \%53,2'si ilçede yaşarken \%46,8'si ise Zonguldak merkezinde ikamet etmektedir. Bu rakamsal verilere bakıldığında; evli bireylerin bekâr bireylere oranla ve ilçede yaşayan bireyler şehir merkezinde yaşayan bireylere oranla daha fazla iç mekân süs bitkileri tercih ettiği sonucu ortaya çıkmaktadır.

Tablo 1b. Demografik özellikler.

\begin{tabular}{|c|c|c|c|c|c|}
\hline $\begin{array}{c}\text { Demografik } \\
\text { özellikler }\end{array}$ & & $\begin{array}{c}\text { İç mekân süs } \\
\text { bitkisi tercih } \\
\text { edenler }\end{array}$ & & $\begin{array}{c}\text { Kesme çiçek süs } \\
\text { bitkisi tercih } \\
\text { edenler }\end{array}$ & \\
\hline \multirow{2}{*}{$\begin{array}{l}\text { Medeni } \\
\text { durum }\end{array}$} & Evli & 41 & 87,2 & 25 & 472 \\
\hline & Bekâr & 6 & 12,8 & 28 & 52,8 \\
\hline \multirow{3}{*}{ İkamet } & Merkez & 22 & 46,8 & 34 & 64,2 \\
\hline & İlçe & 25 & 53,2 & 19 & 35,8 \\
\hline & İlköğretim & 3 & 6,4 & 2 & 3,8 \\
\hline \multirow{3}{*}{ Eğitim } & Lise & 22 & 46,8 & 31 & 58,5 \\
\hline & Önlisans & 8 & 17 & 12 & 22,6 \\
\hline & Lisans & 14 & 29,8 & 8 & 15,1 \\
\hline \multirow{7}{*}{ Meslek } & Serbest & 8 & 17,1 & 4 & 7,5 \\
\hline & Memur & 25 & 53,2 & 10 & 18,9 \\
\hline & İşçi & 5 & 10,6 & 8 & 15,1 \\
\hline & Emekli & 1 & 2,1 & 1 & 1,9 \\
\hline & Ev hanımı & 5 & 10,6 & 4 & 7,5 \\
\hline & Öğrenci & 3 & 6,4 & 25 & 47,2 \\
\hline & İşsiz & - & - & 1 & 1,9 \\
\hline \multirow{4}{*}{ Gelir } & 1000 TL ve altı & 11 & 23,4 & 28 & 52,8 \\
\hline & $1001-2600 \mathrm{TL}$ & 5 & 10,6 & 11 & 20,8 \\
\hline & $2601-4000 \mathrm{TL}$ & 12 & 25,5 & 6 & 11,3 \\
\hline & 4001 TL üstü & 19 & 40,4 & 8 & 15,1 \\
\hline \multirow{3}{*}{ Gelir } & $\begin{array}{l}\text { İç mekân süs } \\
\text { bitkisi tercih } \\
\text { edenler }\end{array}$ & $\mathrm{N}: 47$ & & \multicolumn{2}{|l|}{ St sapma: 1,554} \\
\hline & & & & & \\
\hline & $\begin{array}{l}\text { Kesme çiçek süs } \\
\text { bitkisi tercih } \\
\text { edenler }\end{array}$ & $N: 53$ & & \multicolumn{2}{|l|}{ St sapma: 1,420} \\
\hline
\end{tabular}


Ankete katılan iç mekân süs bitkileri tercih edenlerin eğitim durumlarına bakıldığında; \% 6,4'ü ilköğretim, \% 46,8'i lise, \% 17'si ön lisans ve \% 29,8 'nin lisans mezunu olduğu görülmektedir. Elde edilen verilere göre, eğitim seviyesi arttıkça iç mekân süs bitkisi tüketim yüzdesinin de arttığı görülmektedir. İç mekân süs bitkisin tercih eden meslek grubu memurlar (\% 53,2) iken ve en az tercih eden meslek grubu ise emekliler olmuştur. İç mekân süs bitkisi tüketen bireylerin gelirleri incelendiğinde; 4001 TL ve üstü gelire sahip olan kişi sayısı \% 40,4 (19 kişi) iken, 2601-4000 TL gelire sahip \% 25,5 (12 kişi) ve $1000 \mathrm{TL}$ ve altı gelire sahip kişi sayısı ise \% 23,4 (11 kişi) olduğu saptanmıştır. Bu veriler değerlendirildiğinde; 4001 TL ve üzerinde gelire sahip kişilerin en fazla iç mekân süs bitkisi satın alanlar olduğu ve sonuç olarak gelir düzeyi arttıkça iç mekân süs bitkisi tüketim yüzdesinin arttığı ortaya çıkmaktadır (Tablo 1b).

\section{Ankete katılan kişilerin tüketim tercihleri}

Ankete katılanların 100 kişiden 47 kişi iç mekân süs bitkisini tercih ederken 53 kişi ise kesme çiçek tercih etmiştir. Ankete katılan tüketicilerin tercih nedenleri incelendiğinde; kesme çiçek tercih edenlerin \% 46,2'si gösterişli ve göze hoş gelmesi, $\%$ 15,4'ü bütçesine uygun seçim yapabilmesi, \% $13,5^{\prime} i$ renk çeşitliliğinin fazla olması, \% $11,5^{\prime} i$ ise daha çok çeşit olduğu için tercih etmiştir. İç mekân süs bitkisini tercih etme nedenleri ise; \% 80,9'u kalıcı (uzun ömürlü) olduğu için, \% 10,6'sı estetik ve güzel olması nedeniyle tercih etmiştir (Tablo 2 ).

Tablo 2. Tüketim tercihleri ve nedenleri.

\begin{tabular}{lcc}
\hline Kesme çiçek süs bitkisini tercih etme nedenleri* & \\
\hline & $\begin{array}{c}\text { Kişi } \\
\text { sayısı }\end{array}$ & $\%$ \\
\hline Bakımı zor & 1 & 1,9 \\
Renk çeşitliliği fazla & 7 & 13,5 \\
Bütçeye uygunluk & 8 & 15,4 \\
Daha çok çeşit olması & 6 & 11,5 \\
Gösterişli ve göze hoş gelmesi & 24 & 46,2 \\
Kesme çiçeğe olan özel ilgi & 1 & 1,9 \\
Güzel kokulu olması & 1 & 1,9 \\
Farklı renk ve çeşitte hazırlanabilmesi & 3 & 5,8 \\
Bakım gerektirmemesi & 3 & 5,8 \\
Taşınmasının kolay olması & 1,9 \\
İç mekân süs bitkilerini tercih etme nedenleri & 1 & 80,9 \\
Kalıcı (uzun ömürlü)olması & & 10,6 \\
Estetik ve güzel olması & 38 & 8,5 \\
Aldığı kişinin tercih ediyor olması & 5 & \\
\hline
\end{tabular}

*Birden çok seçenek işaretlendiği için yüzde değerler toplamı \%100 aşmaktadır.

\section{İ̧ mekân süs bitkisini tercih ettikleri özel günler ve tercih ettikleri renk grubu}

Zonguldak ilinde yapılan ve 47 kişinin katıldığı anket sonuçlarına göre iç mekân süs bitkilerini tercih ettikleri özel günler Tablo 3'de gösterilmektedir. Anketten elde edilen verilere göre; yıl içerisinde iç mekân süs bitkilerini alan kişilerin \%34'ünün anneler gününü ve bunu sırasıyla sevgililer günü $(\% 31,9)$ ve yeni iş yeri açılışı için $(\%$ 19,1) tercih ettikleri görülmektedir (Tablo 3). Bu sonuçlar Paiva ve ark. (2020)'nın yaptıkları çalışmayla paralellik göstermektedir. Paiva ve ark. (2020) yaptıkları çalışmada tüketicilerin tarihlere bakılmaksızın tüm yıl çiçek alma alışkanlığına sahip olduklarını belirtmektedir. Bunun yanı sıra tüketicilerin en fazla anneler gününü tercih ettikleri, ardından sevgililer günü ve kadınlar gününü tercih ettikleri bildirilmiştir. Yazıcı
(2020) ise tüketicilerin en fazla sevgililer günü, sonrasında sırayla anneler günü ve öğretmenler gününde iç mekân süs bitkisi tercih ettiklerini belirtmiştir.

Süs bitkileri tüketimini etkileyen önemli faktörlerden biri de cinsiyettir. Bu doğrultuda yapılan Khi kare analizine göre; iç mekân süs bitkisi alırken tercih edilen özel günler ve cinsiyet arasında anlamlı bir ilişki bulunmuştur (p: 0,000< $0,05)$. Sevgililer gününde $\% 92,8$ ile daha çok erkekler satın alımı yaparken, anneler gününde de \% 92,8 ile daha çok kadınların iç mekân süs bitkisi satın aldığı saptanmıştır. Ama renk seçimi ve cinsiyet arasında anlamlı bir ilişki bulunmamıştır ( $p$ : $0,114>0,05)$. Bu durum kadınlar ya da erkekler tarafından özel olarak tercih edilerek öne çıkan belli bir renk tercihi olmadığını göstermektedir. 
Tablo 3. Ankete katılan kişilerin iç mekân süs bitkilerini tercih ettikleri özel günler.

\begin{tabular}{lcc}
\hline \multicolumn{1}{c}{ Özel günler } & Kişi sayısı & $\%$ \\
\hline Hasta ziyareti & 7 & 14,9 \\
Sevgililer günü & 14 & 31,9 \\
Anneler günü & 16 & 34,0 \\
Kadınlar günü & 2 & 4,3 \\
Öğretmenler günü & 2 & 4,3 \\
Yeni iş yeri açılışı & 9 & 19,1 \\
Doğum günü & 4 & 8,5 \\
\hline
\end{tabular}

*iç mekân süs bitkilerini tercih edenler tarafından birden çok seçenek işaretlendiği için yüzde değerler toplamı \%100 aşmaktadır.

Süs bitkileri tüketicilerinin tercihinde önemli rol oynayan özelliklerden biri de renklerdir. Süs bitkilerinde çiçek renginin yanı sıra yaprak, meyve ve kabuk gibi kısımlarının rengi de oldukça etkili olmaktadır. Ankete katılan tüketicilerin iç mekân süs bitkilerinde tercih ettikleri renkler Şekil 1'de belirtilmiştir. Hayatımızı süsleyen renklerin, insan ve toplum üzerinde bıraktığı etki ve anlamlar genişleyebilmekte ve değişebilmektedir. Renk türlerinin insanlar üzerinde göz ardı edilemeyecek düzeyde psikolojik ve görsel etkileri bulunmaktadır (Özçalık ve Eskisarılı, 2019). Anket sonucuna göre iç mekân süs bitkilerinde en fazla beyaz (\% 119,1-56 kişi) renk tercih edilmektedir. Beyaz rengi; saflık, bolluk ve sonsuzluğu anlatırken tazelik, sessizlik, sadelik etkisi de yaratması nedeniyle tüketicilerin tercihlerinde ön plana çıkmış olabilir. Sonrasında sırasıyla genel ifade ile açık renkler (\% 25,5-12 kişi), mor (\% 23,4-11 kişi) ve yeşil (çiçeksiz) (\% 17,0- 8 kişi) renkli iç mekân süs bitkileri tercih edilmiştir. Tüketicilerin en fazla tercih ettiği açık renkler insanlar üzerinde daha ferahlatıcı ve iç açıcı bir his uyandırmasıyla; mor renk de en düşsel, en düşündürücü ve aynı zamanda zenginlik, refah sembolü olmasıyla; tüm renklerin en sakini kabul edilen yeşil rengi ise hayatı, umudu, sevgiyi, bolluk ve bereketi simgelemesiyle tercih sebebi olabilir.

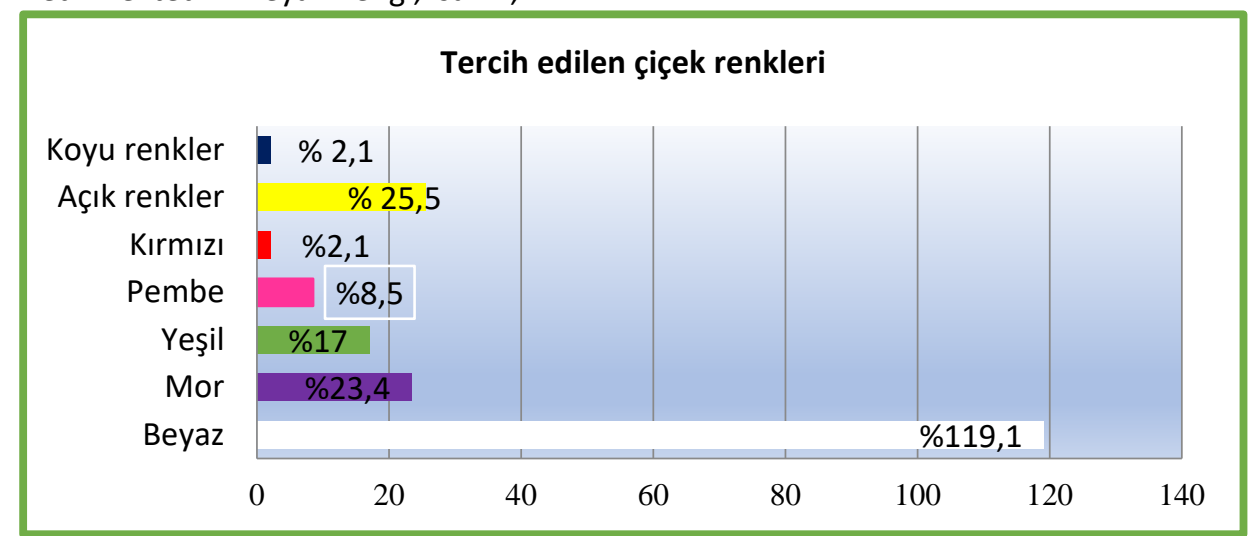

Şekil 1. Ankete katılanların iç mekân süs bitkilerinde tercih ettikleri renk.

*iç mekân süs bitkilerini tercih edenler tarafından birden çok seçenek işaretlendiği için yüzde değerler toplamı \%100 aşmaktadır.

\section{iç mekân süs bitkisinde tercih ettikleri iç mekân süs bitkileri grubu ve satın alma yöntemi}

Ankete katılanların iç mekân süs bitkisi gruplarına göre tercihlerine bakıldığında; \%72,3'ü sukkulent ve kaktüsleri, \%21,3'ü dekoratif çiçekli türleri ve $\% 10,6$ 'sı ise dekoratif yapraklara sahip türleri tercih etmektedir (Şekil 2). Yazıcı (2020) ise yaptığı çalışmada tüketicilerin \%49,1'inin dekoratif çiçekli türleri tercih ettiğini ve bunu sırasıyla sukkulent-kaktüsler ve dekoratif yapraklara sahip türlerin izlediğini belirtmiştir. Ankete katılanlara yöneltilen diğer bir soru ise; iç mekân süs bitkileri temin etme yöntemleri olmuştur. Tüketicilerin \%87,2'si doğrudan satışla almayı tercih ederken, \%12,8'si ise telefonla siparişle satın almaktadır. Çalışmada iç mekân süs bitkileri tüketicileri internet üzerinden satın almayı tercih etmemişlerdir (Şekil 3). Bu sonuçlar Paiva ve ark. (2020)'nın başka bir ülkedeki benzer çalışmasıyla paralellik göstermektedir. Paiva ve ark. (2020)'nın yaptıkları çalışmada da ankete katılanların \%61,5'i çiçekçileri tercih ettiğini, \% 37,8'inin ise süpermarketlerden satın almayı tercih ettiğini belirtilmektedir. Ancak günümüzde ilerleyen teknoloji ve daha da önemlisi tehlikeli pandemi koşulları nedeniyle ilerleyen günlerde yapılacak çalışmalarda internet üzerinden yapılan alışverişler de önemli bir yüzde orana sahip olacaktır. 


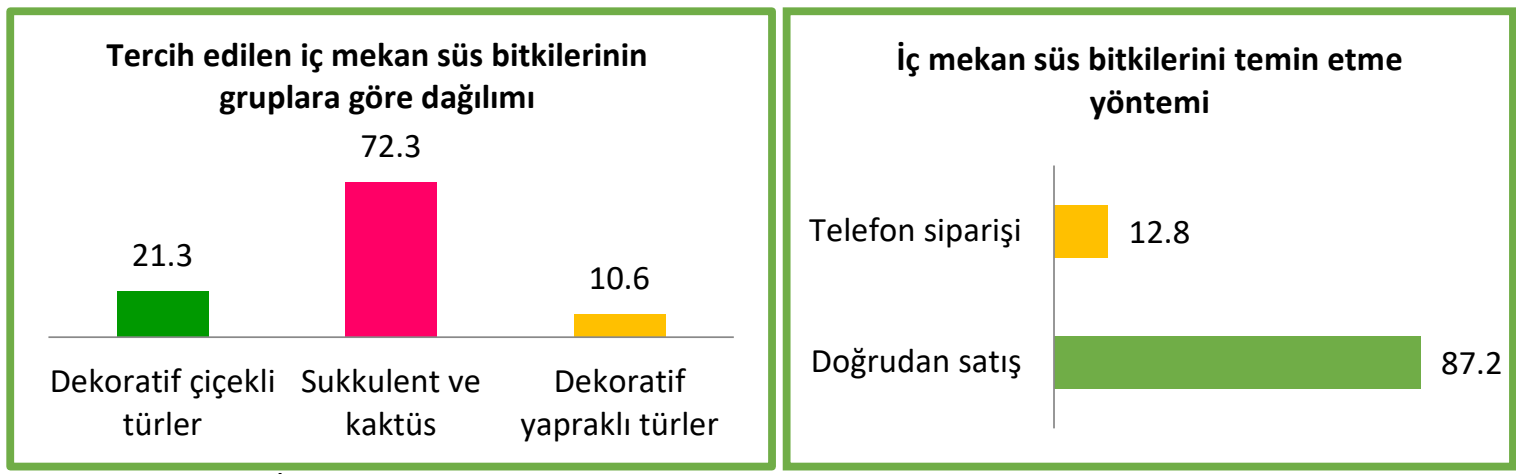

Şekil 2. İç mekân süs bitkilerinin gruplara göre dağılımı Şekil 3. Temin etme yöntemi

\section{Tercih edilen iç mekân süs bitkileri}

Ankete katılan kişiler tarafından 10 farklı iç mekân süs bitkisi tercih edilmiştir. Anket verileri incelendiğinde en fazla satın alınan türler Phalaenopsis sp. (orkide) (\% 52,2) ve sukkulentkaktüsler (\% 10,9)'dir. En az tercih edilen türler Kalanchoe sp. (kalanşo) $(\% 2,2)$ ve Dianthus sp. (karanfil) (\% 2,2)'dir. Sırasıyla tercih edilen diğer türler ise; Saintpaulia ionantha (Afrika menekşesi) $(\% 8,7)$, Dracaena marginata (dragon ağacı) $(\% 6,5)$, Anthurium andreanum (flamingo çiçeği) (\% 6,5), Chamaerops sp. (palmiye) (\% 4,3), Scheflera actinophylla (şeflera) (\% 4,3) ve Ficus elastica (kauçuk) (\% 4,3)'tur. Anket sonuçlarına göre en fazla tercih edilen tür güzel çiçekleri ile dikkat çeken orkide olmuştur (Tablo 4). Ayrıca hemen takip eden kaktüs ve sukulentler grubunun da bakım kolaylığı, susuzluğa olan dayanıkılığı, ayrıca radyasyonu engellediğine dair çalışmaların yapılmış olması, daha çok minyatür yapıda olmalarına bağlı olarak kolay taşınabilmeleri gibi tercih edilmeleri için önemli gerekçeleri bulunmaktadır. İç mekân süs bitkisi alırken; iç mekân süs bitkileri tercihleri ile eğitim düzeyinin dağılımını tespit etmek için Khi kare testi uygulanmıştır. İç mekân süs bitkisi alırken tercih edilen iç mekân süs bitkileri ile eğitim düzeyleri arasında anlamlı bir ilişki bulunmuştur ( $p$ : $0,022<0,05)$. Bu ilişkiye göre lise eğitim seviyesindeki kişilerin daha çok orkide ve sukulent süs bitkilerini tercih ettiği, önlisans ve lisans eğitim seviyesindekiler ise orkide ve daha çok dekoratif yapraklı türlerini tercih ettiği saptanmıştır.

Tablo 4. Tercih edilen iç mekân süs bitkileri.

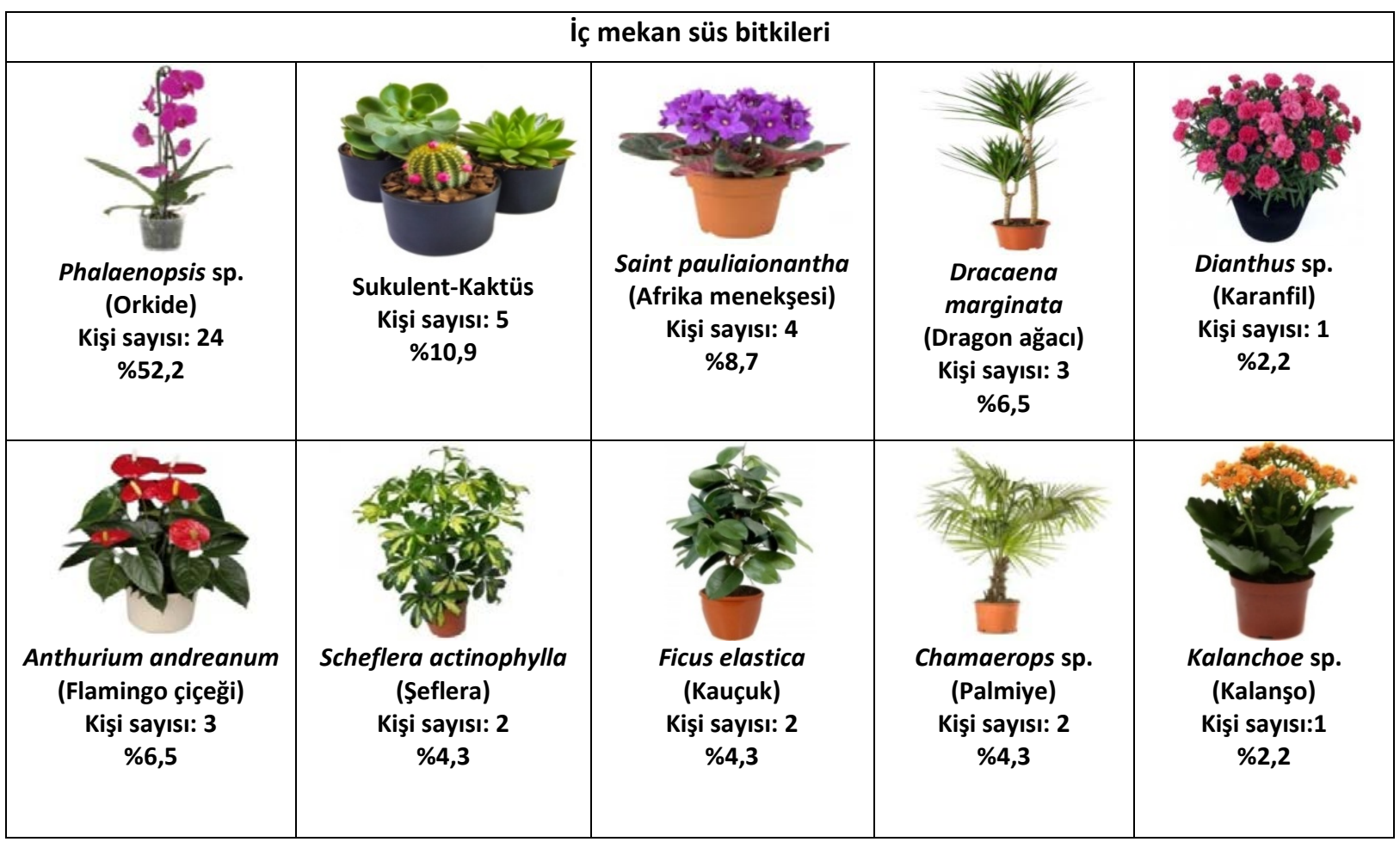




\section{Tercih edilen iç mekân süs bitkilerinde aranan özellikler}

Ankette sorulan bir diğer soru ise tercih edilen iç mekân süs bitkilerinde aranan özellikler olmuştur. Elde edilen veriler 5'li Likert Ölçeği kullanılarak değerlendirilmiştir (Tablo 5). Bu çalışma ortaya çıkan tercih sonuçlarına göre; iç mekân süs bitkileri minyatür olmalıdır 4,34 puan, iç mekân süs bitkilerinde çiçeksiz türler tercih edilmesi 3,39 puan almıştır. İç mekân süs bitkilerinin çiçekli olması önemli olduğu ise 2,55 puan almıştır. İç mekân süs bitkilerinin bulundukları ortamda olumlu etkisi yaratması 1,93 puan ile en düşük puanı almıştır. Oysaki pek çok ülkede yapılan çalışmalarda, iç mekânda bitki bulunmasının hem çalışma ortamındaki verimliliği hem insan psikolojisi üzerindeki etkiyi olumlu yönde arttırdığı belirtilmektedir. Ancak bu çalışmadaki bu grup anket sonucuna bakıldığında, ülkemizin henüz bu bilinçliliğe yeterli oranda ulaşamamış olduğu sonucu ortaya çıkmaktadır. İç mekân süs bitkilerinin çiçekli türlerinden olmasının önemli olduğu fikrine, ankete katılanların \%9'u kesinlikle katılırken, \% 50'si katılmaktadır. Ankete katılanların \% 52'si iç mekân süs bitkilerinin minyatür olmasına kesinlikle katılmamaktadır. İç mekân süs bitkilerinin kokulu olması özelliğine \% 9'u kesinlikle katılırken, \% 31'i katılmaktadır. Ayrıca iç mekân süs bitkilerinin her evde bulunması gerektiğine ise \% 40'ı katılırken, \% 5'i kesinlikle katılmaktadır.

Tablo 5a. Tercih edilen iç mekân süs bitkilerinde aranan özellikler ile ilgili görüşler.

\begin{tabular}{|c|c|}
\hline İç mekân bitki tercihleri & Ortalama \\
\hline S1. İç mekân süs bitkisinin çiçekli olması önemlidir. & 2,55 \\
\hline S2. iç mekân süs bitkilerinin kolay bakılabilmesi önemli bir unsurdur. & 2,23 \\
\hline S3. İç mekan süs bitkilerinde aranjman önemlidir. & 2,49 \\
\hline S4. İç mekân süs bitkilerinde çiçeksiz olan türler tercih edilmelidir. & 3,39 \\
\hline S5. İç mekân süs bitkilerinde çiçek renkleri önemlidir. & 2,59 \\
\hline S6.iç mekân süs bitkilerinde saksı seçimi önemlidir. & 2,22 \\
\hline S7. iç mekân süs bitkileri her evde bulunması gerekir. & 2,78 \\
\hline S8. İç mekân süs bitkilerinin balkon veya salonda konumlandırıldığı yer ihtiyaçlarına göre belirlenmelidir. & 2,31 \\
\hline S9. İç mekân süs bitkileri bulundukları ortamda olumlu etki yaratırlar. & 1,93 \\
\hline S10.ìç mekân süs bitkilerinin çiçeklerin kokulu olması gerekir. & 2,95 \\
\hline S11. İç mekân süs bitkilerinin saksıların veya toprağının yılda bir kez değiştirilmesi gerekmektedir. & 2,25 \\
\hline S12. İç mekân süs bitkilerinde bitki boyu önemlidir. & 3,25 \\
\hline S13. İç mekân süs bitkileri minyatür olmalıdır. & 4,34 \\
\hline
\end{tabular}

Tablo 5b. Tercih edilen iç mekân süs bitkilerinde aranan özellikler ile görüşler (\%).

\begin{tabular}{|c|c|c|c|c|c|c|c|c|c|c|c|c|c|}
\hline & S1 & S2 & S3 & S4 & S5 & S6 & S7 & S8 & S9 & S10 & S11 & S12 & S13 \\
\hline $\begin{array}{l}\text { Kesinlikle } \\
\text { katılıyorum }\end{array}$ & $\% 9$ & $\% 10$ & $\% 5$ & $\% 3$ & $\% 11$ & $\% 13$ & $\% 5$ & $\% 9$ & $\% 27$ & $\% 9$ & $\% 26$ & $\% 2$ & $\% 2$ \\
\hline Katılıyorum & $\% 50$ & $\% 61$ & $\% 49$ & $\% 23$ & $\% 40$ & $\% 62$ & $\% 40$ & $\% 56$ & $\% 55$ & $\% 31$ & $\% 48$ & $\% 18$ & $\% 2$ \\
\hline Kararsızım & $\% 20$ & $\% 26$ & $\% 38$ & $\% 16$ & $\% 29$ & $\% 16$ & $\% 33$ & $\% 31$ & $\% 16$ & $\% 21$ & $\% 12$ & $\% 42$ & $\% 8$ \\
\hline Katılmıyorum & $\% 19$ & $\% 2$ & $\% 8$ & $\% 48$ & $\% 19$ & $\% 8$ & $\% 16$ & $\% 3$ & $\% 2$ & $\% 34$ & $\% 3$ & $\% 29$ & $\% 36$ \\
\hline $\begin{array}{l}\text { Kesinlikle } \\
\text { katılmıyorum }\end{array}$ & $\% 2$ & $\% 1$ & - & $\% 10$ & $\% 1$ & $\% 1$ & $\% 6$ & $\% 1$ & - & $\% 5$ & $\% 11$ & $\% 9$ & $\% 52$ \\
\hline
\end{tabular}

1: Kesinlikle katılıyorum 2: Katılıyorum 3:Kararsızım 4:Katılmıyorum 5:Kesinlikle katılmıyorum

\section{Sonuç ve Öneriler}

Süs bitkileri; goncası, yaprağı, dalı, meyve ve çiçekleri ile estetik ve fonksiyonel özellikleriyle kullanıldıkları alanlarda ön plana çıkmaktadır. Insanların süs bitkilerini satın alma kararında ise estetik değerinin yanı sıra tüketicilerin talebi, demografisi, satın alma vesileleri ve dönemleri etkili olmaktadır. Tüketicilerin süs bitkilerini alıp almama konusunda nasıl seçim yaptıklarını ve satın alma yoğunluğunun ve sıklığının belirlenmesi, süs bitkilerine olan talebi anlamak açısından önem arz etmektedir.

Bu araştırmada Zonguldak kentinde tercih edilen iç mekân süs bitkileri ve tüketici tercihleri belirlenmiştir. Bu çalışma sonuçlarına göre, kadınların süs bitkilerine olan ilgileri, erkeklere 
oranla daha fazladır. Anket sonuçları değerlendirildiğinde; ankete katılanların çoğunluğu, 31-45 yaş aralığında ve evli bireylerden oluşmaktadır. Çalışmaya göre en fazla tercih edilen iç mekân süs bitkisi Phalaenopsis sp. (orkide) olup bunu sırasıyla sukkulent-kaktüsler ve Saintpaulia ionantha (Afrika menekşesi) izlemektedir. Ankete katılanların, iç mekân süs bitkilerini tercih etmelerinin en önemli nedeni, kalıcı (uzun ömürlü) olmasıdır. Anket sonucuna göre iç mekân süs bitkilerinde en fazla beyaz renk tercih edilmektedir. Yıl içerisinde iç mekân süs bitkilerini alan kişilerin \% 34 'ü anneler günü ve \% 31,9'u ise sevgililer günü için tercih etmiştir. Bunun yanı sıra tüketiciler iç mekân süs bitkilerini; \% 87,2 oranında doğrudan satışla almayı tercih ederken, \% 12,8 oranında ise telefonla siparişle satın almaktadır. Bu doğrultuda mevcut araştırma, Zonguldak ilinde süs bitkilerinde satın alma ve tüketim alışkanlıklarının temel özelliklerini ortaya koymak ve gelecekteki ana eğilim ve fırsatlara işaret etmeyi amaçlamaktadır. Süs bitkileri, günümüzde dünya üzerinde giderek gelişen ve hızlı değişim gösteren bir sektördür. Süs bitkileri pazarının büyümesinin nedenlerinden biri, çoğu üründe çiçekçilere göre daha düşük bir değer sundukları için çiçek perakendecileri ile güçlü bir rekabet içinde olan süpermarketlerde süs bitkilerinin satışa sunulmasıdır (Junqueira ve Peetz, 2017; Paiva ve ark. 2020). Süpermarketlerin yanı sıra büyük mağazalar ve özellikle son bir yıldır tüm dünyada son derece önem taşıyan ve hijyen koşullarının çok dikkat edilmesi, insanların birbirleriyle temas etmemesi, gereğini ön plana çıkaran pandemi nedeniyle internet tabanlı işletmeler gibi kitlesel perakendeciler, süs bitkileri sektöründe önemli rol oynamaktadır. Bu nedenle süs bitkisi tüketicilerinin sosyo-demografik özellikleri ve satın alma sıklığındaki etkilerinin bilinmesiyle yapılan reklam ve promosyonlar belirli grupları hedeflemek için kullanılabilir.

Yıllardır gerek ülkemizde gerekse dünyada süs bitkileri, oldukça önemli bir geçim kaynağıdır. Bu nedenle sektör bazında gerek iç pazarın canlanması, gerekse dış ticaretin arttırılması açısından tüketicilerin tercihlerinin bilinerek üretim ve pazarlama ağının bu bilgiler ve veriler doğrultusunda düzenlenmesi, hem milli gelir hem ülke ekonomisi açısından son derece önem taşımaktadır.

Teşekkür: Bu çalışmada, süs bitkisi tüketicilerine Zonguldak'ta süs bitkileri satışı yapan Doğa Çiçekçilik aracılığıyla ulaşılmıştır.

Çıkar Çatışması Beyanı: Makale yazarları aralarında herhangi bir çıkar çatışması olmadığını beyan ederler.
Araştırmacıların Katkı Oranı Beyan Özeti: Yazarlar makaleye eşit oranda katkı sağlamış olduklarını beyan ederler.

\section{Kaynaklar}

Akça, Ş. B., Yazııı, K., Karaelmas, D. (2019). Zonguldak ili Kesme Çiçek Perakendecilerinin Analizi, Bartın Orman Fakültesi Dergisi, 21(3), 580-588. DOI: 10.24011/barofd.541447.

Anacleto, A., Fujita, E. S., Mendes, L. P., Vıeıra, R. M., Pereira, R. T. (2017). Profile and behavior of elderly flower consumer in Parana Coast. Ornamental Horticulture, v.23,n.3, p.337-344. DOI: 10.14295/oh.v23i3.1029.

Büyükbay, Oruç, E., Sayılı, M., Uzunöz, M. (2009). Tüketicilerin Sosyo- Ekonomik Özellikleri İle Salça Tüketimleri Arasındaki iliş̧ki: Tokat ili Örneği, Gıda Teknolojileri Elektronik Dergisi Cilt: 4, No: 1, 2009 (17).

Dijkstra, K., Pieterse, M. E., Pruyn, A. (2008). Stress reducing effects of indoorplants in the built health care environment. Preventive Medicine 47:279-283.

Gözener, B., Sayılı, M. (2013). Tüketicilerin Açık Süt ve Süt Ürünleri Tüketim Tercihlerinin Incelenmesi: Tokat-Turhal İlçesi Örneği. Sosyal Bilimler Araştırmaları Dergisi, 8 (1) , 160-175.

Husti, A., Contıu, I., Radu, M., Neacşu, I., Cantor, M. (2015). Psychological Benefits of Ornamental Plants Used in Office Environments. Bulletin of University of Agricultural Sciences and Veterinary ClujNapoca: Horticulture, 72, 101-107.

Junqueıra, A. H., Peetz, M. S. (2017). Brazilian consumption of flowers and ornamental plants: habits, practices and trends. Ornamental Horticulture. V.23, n.2, p.178184, DOI: 10.14295/oh.v23i2.1070.

Kellert, S. (2005). Designing and understanding the human-nature connection. Washington Island.

Özçalık, M. ve Eskisarılı, Ş. (2019). Peyzaj Mimarlığında Renk Olgusu. Uluslararası Uygur Araştırmaları Dergisi, Sayı: 2019/14, s. 60-74.

Paiva, Patricia Duarte de Oliveira., Reis, Michele Valquiriados., Sant'Ana, Gabriela Silva., Bonifacio, Francilene de Lourdes., Guimaraes, Paulo Henrique Sales. (2020). Flower and ornamental plant consumers profile and behavior. Ornamental Horticulture. 26(3), 333- 
345.https://doi.org/10.1590/2447-

536x.v26i3.2158.

Sayılı, M., Gözener, B. (2013). Trabzon ili Of Illçesi'nde Ailelerin Çay Tüketim Durumu ve Alışkanlıkları. Gıda Teknolojileri Elektronik Dergisi, 8(2): 1-7.

Schimmenti, E., Galati, A., Borsellino, V., Levoli, C., Lupi, C., Tinervia, S. (2013). Behaviour of consumers of conventional and organic flowers and ornamental plants in Italy. Hort. Sci. (Prague), 40. 162-171.

Selim, C., Akgün, İ., Olgun, R. (2020). Ofislerde Kullanılan iç Mekân Bitki Tercihlerinin, Bakım Olanaklarının ve Hava Kalitesi Üzerine Etkilerinin Değerlendirilmesi; Akdeniz Üniversitesi Örneği. Türk Tarım-Gıda Bilim ve Teknoloji Dergisi, 8(3): 702-713,2.

Sezen, I., Aytatlı, B., Ağrılı, R., Patan, E. (2017). İç mekân tasarımında bitki kullanımının birey ve mekân üzerine etkileri. ATA Planlama ve Tasarım Dergisi, 1(1):25-34.

Titiz, S., Çakıroğlu, N., Biriş̧̧i, T., Çakmak, S. (2000a). Süs Bitkileri Üretim ve Ticaretindeki Gelişmeler. Presented at the V. Türkiye Ziraat Mühendisliği Teknik Kongresi, Ankara.

Titiz, S., Çakıroğlu, N., Birişçi, T., Çakmak, S. (2000b). Süs Bitkileri Üretim ve Ticaretindeki Gelişmeler. Presented at the V. Türkiye Ziraat Mühendisliği Teknik Kongresi, Ankara.
Ulrich, R. S. (1984). View through a window may influencere covery from surgery. Science 224:420-421.

Yazgan, M. E., Uslu, A., Özyavuz, M. (2009). İç Mekân Bitkileri ve Tasarımı. Ankara Üniversitesi Yayın No: 1575, Ders kitabı:527, Ankara Üniversitesi Basımevi. $280 \mathrm{~s}$.

Yazıcı, K., Gülgün, B. (2016). TR83 illerinde Süs Bitkileri Sektörünün Mevcut Durumu ve Geliştirilmesi Üzerine Bir Araştırma. Selçuk Tarım Bilimleri Dergisi, 3(1), 18-24.

Yazıcı, K. (2020). İç mekân Süs Bitkilerinin Önemi ve Tüketici Eğilimlerinin Belirlenmesi. Bartın Orman Fakültesi Dergisi, 22(3), 738-747.

Yeşilayer, A., Yazıcı, K., Dipi, E. (2019). Ziraat, Orman ve Su Ürünleri Alanında Araştırma Makaleleri Bölüm Adı: Bölüm 1: Tokat İli Süs Bitkileri Yetiştiriciliğinde Üreticilerin Karşılaştıkları Bitki Koruma Sorunları. Yayın Yeri: Gece Akademi, ISBN:978-625-7958-103, Bölüm Sayfaları:7 -26.

Zencirkıran, M., Çelik, B., Müdük, B., Görür, A., Çetiner, S., Eraslan, E., Tanrıverdi, D. (2018). İç Mekân Tasarım Bitkilerinin Kullanıcılar için Toksik Özellikler Bakımından Değerlendirilmesi. Bartın Orman Fakültesi Dergisi. 20(1), 26-31. 